Original Article

\title{
Enzymatic activity of bone markers on Lithobates catesbeianus (Shaw, 1802) growth during the ossification process
}

\author{
Atividade enzimática de marcadores ósseos no crescimento de Lithobates catesbeianus \\ (Shaw, 1802) durante o processo de ossificação
}

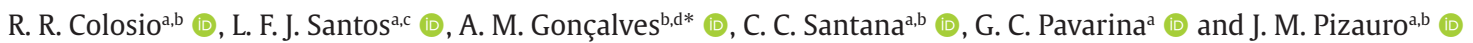 \\ aUniversidade Estadual Paulista “Júlio de Mesquita Filho" - UNESP, Faculdade de Ciências Agrárias e Veterinárias, Departamento de Tecnologia, \\ Jaboticabal, SP, Brasil \\ bUniversidade Estadual Paulista "Júlio de Mesquita Filho" - UNESP, Instituto de Química, Departamento de Bioquímica e Química Orgânica, \\ Araraquara, SP, Brasil \\ 'Faculdade de Tecnologia - FATEC, Ribeirão Preto, SP, Brasil \\ dUniversidade de Araraquara - UNIARA, Departamento de Ciências Biológicas e de Saúde, Araraquara, SP, Brasil
}

\begin{abstract}
In order to better understand the ossification processes in anurans our study was carried out on tadpoles and adults of Lithobates catesbeianus. In this sense, we characterized the kinetic properties of alkaline phosphatase with $p$-nitrophenylphosphatase ( $p \mathrm{NPP}$ ) and pyrophosphate (PPi) and evaluated the activities of tartrate-resistant acid phosphatase and acid phosphatase. The enzyme extracts were obtained from tadpoles and adult femurs, which were divided into epiphysis and diaphysis. After homogenization, the samples were submitted to differential centrifugation to obtain cell membranes and, further, to phospholipase C (PIPLC) treatment, to remove membrane-bound proteins anchored by phosphatidylinositol. The average of specific activity for $p$ NPP hydrolysis (at $\mathrm{pH} 10.5$ ) by alkaline phosphatase released by phosphatidylinositol-specific phospholipase C (PIPLC) from Bacillus cereus among different bone regions at different animal ages was 1,142.57 $\mathrm{U.mg}^{-1}$, while for PPi hydrolysis (at pH 8.0), it was 1,433.82 $\mathrm{U.mg}^{-1}$. Among the compounds tested for enzymatic activity, the one that influenced the most was EDTA, with approximately $67 \%$ of inhibition for pNPPase activity and $77 \%$ for PPase activity. In the case of kinetic parameters, the enzyme showed a "Michaelian" behavior for $p$ NPP and PPi hydrolysis. The $K_{\mathrm{m}}$ value was around $0.6 \mathrm{mM}$ for $p$ NPPase activity and ranged from 0.01 to $0.11 \mathrm{mM}$ for PPase activity, indicating that the enzyme has a higher affinity for this substrate. The study of $p$ NPP and PPi hydrolysis by the enzyme revealed that the optimum pH of actuation for $p$ NPP was 10.5, while for PPi, which is considered the true substrate of alkaline phosphatase, was 8.0, close to the physiological value. The results show that regardless of the ossification type that occurs, the same enzyme or isoenzymes act on the different bone regions and different life stages of anurans. The similarity of the results of studies with other vertebrates shows that anurans can be considered excellent animal models for the study of biological calcification.
\end{abstract}

Keywords: anura, biological calcification, metamorphosis, phosphatases, kinect characterization.

\begin{abstract}
Resumo
Para melhor compreender o processo de ossificação em anuros, nosso estudo foi conduzido em girinos e adultos de Lithobates catesbeianus. Nesse sentido, as propriedades cinéticas da fosfatase alcalina com $p$-nitrofenilfosfato ( $p$ NPP) e pirofosfato (PPi) foram caracterizadas, e as atividades enzimáticas das fosfatases ácida e ácida tartarato resistente foram avaliadas. Os extratos enzimáticos foram obtidos de fêmur de girinos e adultos, divididos em epífise e diáfise. Após a homogeneização as amostras foram submetidas à centrifugação diferencial para obter membrana celular e, em seguida, ao tratamento com fosfolipase C (PIPLC), para remover as proteínas de membrana ancoradas por fosfatidilinositol. A média da atividade específica da fosfatase alcalina, liberada pela PIPLC de Bacillus cereus, para a hidrólise de $p$ NPP ( $\mathrm{pH} \mathrm{10,5)} \mathrm{nas} \mathrm{diferentes} \mathrm{regiões} \mathrm{do} \mathrm{fêmur} \mathrm{e} \mathrm{idades} \mathrm{dos} \mathrm{animais} \mathrm{foi} \mathrm{de} \mathrm{1.142,57} \mathrm{U.mg-1,}$ enquanto para a hidrólise do PPi ( $\mathrm{pH} \mathrm{8,0)}$ foi de 1.433,82 U.mg-1. Entre os compostos testados para a atividade enzimática, o de maior influência foi o EDTA, inibindo aproximadamente $67 \%$ e $77 \%$ das atividades de pNPPase e PPase, respectivamente. Quanto aos parâmetros cinéticos, a enzima apresentou comportamento Michaeliano para a hidrólise dos dois substratos. 0 valor de $\mathrm{K}_{\mathrm{m}}$ foi de $0,6 \mathrm{mM}$ para a atividade de $p$ NPPase e variou de $0,01 \mathrm{a}$ 0,11 para a atividade de PPase, indicando uma maior afinidade por esse substrato. 0 estudo da hidrólise de $p$ NPP e PPi revelou que o pH ótimo aparente de atuação foi de 10,5 para o pNPP e 8,0 para o PPi, próximo ao fisiológico,
\end{abstract}

*e-mail: amgoncalves@uniara.edu.br

Received: May 7, 2021 - Accepted: July 15, 2021

This is an Open Access article distributed under the terms of the Creative Commons Attribution License, which permits unrestricted use, distribution, and reproduction in any medium, provided the original work is properly cited. 
sendo que esse é considerado o substrato natural da fosfatase alcalina. Os resultados demonstram que, apesar do tipo de ossificação que ocorre, a mesma enzima ou isoenzimas, atuam nos diferentes locais do osso e estágios de vida dos anuros. A similaridade dos estudos com os realizados com outros vertebrados apontam que os anuros podem ser considerados excelentes modelos animais para o estudo da calcificação biológica.

Palavras-chave: anura, calcificação biológica, metamorfose, fosfatases, caracterização cinética.

\section{Introduction}

The process of amphibian metamorphosis, characterized by behavioral, morphological, physiological and biochemical changes, is a classic model used to study the transition of vertebrates from an aquatic to a terrestrial environment (Bo et al., 2018; Gao et al., 2018; Kroth et al., 2018; Rigon et al., 2014).

Among the alterations, the morphological and the physiological ones are more easily perceptible, characterized by the regression of structures necessary only to tadpoles, by the transformation of some larval structures into structures necessary for adults, and by the development of structures only essential to adult animals (Bo et al., 2018; Gao et al., 2018).

Modifications of the skeletal system, more specifically the development of the forelimbs and hindlimbs, are critically important to anurans (Gao et al., 2018; Trueb and Hanken, 1992) to move in the terrestrial environment by jumping (Fabrezi et al., 2017; Pough et al., 2008).

The skeleton consists mainly of bone tissue, a specialized type of connective tissue, which is composed of bone matrix (mineralized extracellular material), and cells called osteoblasts, osteocytes and osteoclasts (Junqueira and Carneiro, 2013; Pizauro Junior et al., 2017). Bone formation, as well as fracture repair, occurs through two processes called intramembranous ossification and endochondral ossification (Junqueira and Carneiro, 2013; Song et al., 2010).

In vertebrates in general, the development of long bones occurs from the combination of two osteogenesis mechanisms, in which periosteal intramembranous ossification is accompanied by endochondral ossification (Çiçek et al., 2011; Felisbino and Carvalho, 1999, 2001; Gómez et al., 2017; Junqueira and Carneiro, 2013; Pizauro Junior et al., 2017; Song et al., 2010). In amphibians, this process occurs mainly by periosteal ossification, which advances from the center of the long bones (diaphysis) towards the bone end (epiphysis) faster than the endochondral ossification (Çiçek et al., 2011; Felisbino and Carvalho, 1999, 2001; Fröbisch, 2008; Gómez et al., 2017).

Biological calcification occurs through the formation of hydroxyapatite crystals, requiring the release and transport of inorganic phosphate (Pi) into extracellular matrix vesicles (EMV), which originate from osteoblast membrane surface, being a process performed by the coordinated action of enzymes (Millán, 2013; Pizauro Junior et al., 2017).

Inside the EMV, initial Pi production is performed by PHOSPHO1, which catalyzes the hydrolysis of phosphocholine and phosphoethanolamine by releasing Pi. Such substrates are formed from the hydrolysis of phospholipids: phosphatidylcholine, phosphatidylethanolamine and sphingomyelin, located on the inner side of the vesicle membrane, by the action of phospholipases and sphingomyelinase 2. On the outside of the EMV, PC- 1 is responsible for the production of the alkaline phosphatase substrate, PPi, derived from ATP hydrolysis, that is hydrolyzed by alkaline phosphatase and a Pi is released. Finally, calcium is translocated into the vesicle by annexins, which act as calcium channels, while Pi is translocated into the EMV by carriers. Thus, the increase of the calcium versus phosphate ionic product within the vesicles leads to calcium phosphate precipitation, leading to the formation of crystals that perforate the vesicle membrane and spill, exposing preformed hydroxyapatite to the extracellular fluid, allowing the propagation and deposition of hydroxyapatite on collagen fibers present in the extracellular matrix (Millán, 2013; Pizauro Junior et al., 2017).

Among the enzymes involved in the biological calcification process, alkaline phosphatase has been used as a specific biochemical marker for osteoblasts, the cells responsible for bone formation, while tartrate-resistant acid phosphatase has been used as a marker for osteoclasts, the cells responsible for resorption the bone tissue (Gijsbers et al., 2001; Johnson et al., 2000). Therefore, the study of these enzymes may provide important information about the metabolic activity of this tissue.

During the anurans metamorphosis period, the formation and then the growth of the limbs of the animal occur, through both of the ossification processes (Felisbino and Carvalho, 1999, 2001; Gómez et al., 2017). In the case of birds and mammals, when the animal is born, the limbs are already formed, thus only bone growth is observed from then on (Pizauro Junior et al., 2017). Because of this, the tadpoles and frogs of the species Lithobates catesbeianus were chosen as a model to study periosteal and endochondral ossification, processes required not only during bone tissue development and growth, but also during fracture repair (Song et al., 2010). In addition, the study, through the kinetic characterization of alkaline phosphatase released by PIPLC and the activity of acid phosphatase and tartrate-resistant acid phosphatase, and understanding the role of these enzymes may help prevent and/or cure certain bone pathologies (Junqueira and Carneiro, 2013; Pizauro Junior et al., 2017), in anurans and other vertebrates.

The present work characterized the kinetic properties of alkaline phosphatase and studied the activities of tartrateresistant acid phosphatase and acid phosphatase. These enzymes are associated with mineralization, resorption and bone tissue formation processes. In this sense, the results may contribute to better understand anuran bone formation, as well as to demonstrate the potential of amphibians as excellent animal models for the study of the biological mineralization process. 


\section{Material and Methods}

The animal procedures as well as the manipulation and sacrifice protocols used in this study were approved by the Animal Use Ethics Commission (Comissão de Ética no Uso de Animais - CEUA) of the Faculty of Agriculture and Veterinary Sciences (Faculdade de Ciências Agrárias e Veterinárias - FCAV), protocol No.10315/15, and are therefore in accordance with the Ethical Principles on Animal Experimentation (Princípios Éticos na Experimentação Animal), adopted by the Brazilian College of Animal Experimentation (Colégio Brasileiro de Experimentação Animal).

The experiments were carried out at the Frog Farming Sector of the Aquaculture Center of UNESP (CAUNESP), and at the Laboratory of Applied Enzymology and Immunochemistry (Laboratório de Enzimologia e Imunoquímica Aplicadas - LEIA) of the Technology Department of UNESP, Campus of Jaboticabal in São Paulo, Brazil.

\subsection{Experimental animals}

Bullfrog (Lithobates catesbeianus) tadpoles were kept in tanks with 2,000 L of capacity and a density of one tadpole per $2 \mathrm{~L}$ of water, with an average temperature of $27^{\circ} \mathrm{C}$. For food, a commercial ration was provided three times a day until apparent satiation. Tadpoles $(n \approx 500)$ were collected between stages 42 and 46 (metamorphic climax), according to Gosner (1960) table, during which the largest limb development occurs.

The frogs were housed in bays of approximately $12 \mathrm{~m}^{2}$, containing shelter sites, central water chutes and linearly arranged vibratory feeders. Continuous flow of water was provided from an artesian well. A commercial ration was provided. According to the needs of the experiment frogs were collected $(n \approx 50)$, in growth phase, approximately six months after metamorphosis (from 9 months to 1 year old).

\subsection{Slaughtering animals and obtaining bones for the production of enzyme extracts}

To obtain the enzyme extracts, the animals were desensitized in water with ice at $\approx 4{ }^{\circ} \mathrm{C}$, the tadpoles were decapitated (Czesnik et al., 2006), by separating the head from the body, and the frogs were submitted to a concussion of the spinal marrow. The hind limbs were then collected, immediately frozen in liquid nitrogen, and stored separately at $-70{ }^{\circ} \mathrm{C}$.

After thawing, the soft and adherent tissues were removed from the femurs. Then, bone marrow was removed, and the femurs were divided into epiphysis and diaphysis, ground separately in a mill-type appliance (TECNAL brand, model TE 631), and then homogenized in a TURRAX type apparatus (OMNI brand, model GLH-2511), in TRIS. $\mathrm{HCl}$ buffer $5 \mathrm{mM}$, $\mathrm{pH}=7.5$ containing $2 \mathrm{mM} \mathrm{MgCl}_{2}$ and $1 \mu \mathrm{M} \mathrm{ZnCl}$, in the proportion of $1 \mathrm{~g}$ of tissue to $5 \mathrm{~mL}$ of buffer. The homogenate was centrifuged at $10,000 \mathrm{~g}$ for 10 minutes at $4{ }^{\circ} \mathrm{C}$ (see Supplementary Figure 1$)$. Thereafter, a predetermined amount of supernatant (SEB) was aliquoted, frozen in liquid nitrogen and stored at $-70{ }^{\circ} \mathrm{C}$ for use in subsequent assays. The remaining SEB was used for differential centrifugation.

\subsection{Differential centrifugation to obtain cell membranes}

The supernatant (CES) was again centrifuged at $100,000 \mathrm{~g}$ for $2 \mathrm{~h}$ at $4{ }^{\circ} \mathrm{C}$. Then the supernatant (S1) was aliquoted, and the precipitate (P1) was solubilized in a POTTER type homogenizer with $5 \mathrm{mM}$ TRIS. $\mathrm{HCl}$ buffer, $\mathrm{pH}=7.5$ containing $2 \mathrm{mM} \mathrm{MgCl}_{2}$ and $1 \mu \mathrm{M} \mathrm{ZnCl}_{2}$ (see Supplementary Figure 1). A predetermined amount of P1 was aliquoted and the remaining was used in the next purification steps.

\subsection{Removal of cell membrane-bound proteins via phosphatidylinositol anchor}

Sample P1 was incubated with phospholipase C (1 U PIPLC/mL sample) in $5 \mathrm{mM}$ TRIS. $\mathrm{HCl}$ buffer, $\mathrm{pH}=7.5$, containing $2 \mathrm{mM} \mathrm{MgCl}_{2}$ and $1 \mu \mathrm{M} \mathrm{ZnCl}_{2}$, at $37{ }^{\circ} \mathrm{C}$ for $1 \mathrm{~h}$, while kept under constant agitation (Pizauro Junior et al., 1995). After the incubation period, the mixture was centrifuged at $100,000 \mathrm{~g}$ for two hours at $4{ }^{\circ} \mathrm{C}$. The obtained supernatant was frozen and stored. The precipitate was solubilized in a POTTER-type homogenizer using the same initial volume of $5 \mathrm{mM}$ TRIS. $\mathrm{HCl}$ buffer, $\mathrm{pH}=7.5$, containing $2 \mathrm{mM} \mathrm{MgCl}_{2}$ and $1 \mu \mathrm{M} \mathrm{ZnCl}_{2}$ (Pizauro Junior et al., 1988) (see Supplementary Figure 1 ). The precipitate and the supernatant were used to evaluate the type of enzyme interaction with the membrane.

\subsection{Determination of enzymatic activities}

The $p$-nitrophenylphosphatase ( $p$ NPPase) activity of phosphatases was determined discontinuously at $37{ }^{\circ} \mathrm{C}$ through the formation of the $p$-nitrophenolate ion $\left(\varepsilon=17600 \mathrm{M}^{-1} \mathrm{~cm}^{-1}, \mathrm{pH}=13\right)$, in $100 \mathrm{mM}$ AMPOL buffer, $\mathrm{pH}=10.5$ (alkaline phosphatase) containing $2 \mathrm{mM} \mathrm{MgCl}$, or $100 \mathrm{mM}$ Acetate buffer, $\mathrm{pH}=5.0$ (acid phosphatase and tartrate resistant acid phosphatase), both containing $1 \mathrm{mM}$ pNPP in a volume of $1 \mathrm{~mL}$. In the case of tartrate-resistant acid phosphatase, sodium tartrate $(100 \mathrm{mM})$ was added to the acetate buffer. The reaction was always initiated by the addition of the enzyme to the reaction medium and stopped by the addition of $1 \mathrm{~mL}$ of $1 \mathrm{M} \mathrm{NaOH}$ at previously established times. Then, the measurement was performed on a Hitachi ${ }^{\circledR}$ U-2000 spectrophotometer at $410 \mathrm{~nm}$.

The pyrophosphatase activity of alkaline phosphatase (PPase) was determined discontinuously at $37{ }^{\circ} \mathrm{C}$ by measuring the phosphate released according to the method described by Heinonen and Lahti (1981). The reaction was initiated by the addition of the enzyme to the reaction medium containing $100 \mathrm{mM}$ TRIS. $\mathrm{HCl}$ buffer, $\mathrm{pH}=8.0$, in a final volume of $1 \mathrm{~mL}$. At pre-established times the reaction was stopped by the addition of $0.5 \mathrm{~mL}$ of cold TCA $30 \%$ $(\mathrm{w} / \mathrm{v})$ solution and $0.5 \mathrm{~mL}$ aliquots were used for measuring the inorganic phosphate released. Then, the measurement was performed on a Hitachi® U-2000 spectrophotometer at $355 \mathrm{~nm}$.

The determinations were performed in triplicates with initial velocities remaining constant for at least 90 minutes with less than $5 \%$ of the substrate being hydrolyzed. 
Controls without enzyme addition were included in each experiment to estimate non-enzymatic substrate hydrolysis.

One unit of enzymatic activity was defined and expressed as the amount of enzyme that releases one nmol of $p$-nitrophenolate ( $p$ NPPase activities) or phosphate (PPase activity) per minute per milligram of protein $\left(\mathrm{U}_{\mathrm{mg}}{ }^{-1}\right)$ under the standard test conditions.

\subsection{Effect of $\mathrm{pH}$ on enzymatic activities in the SPIPLC fraction}

The effect of $\mathrm{pH}$ on the $p$ NPPase and PPase activities of PIPLC-released alkaline phosphatase was studied using the buffer solutions: TRIS.HCl $(\mathrm{pH}=6.5-8.5)$ and AMPOL $(\mathrm{pH}=8.5-11.0)$ at a concentration of $100 \mathrm{mM}$.

\subsection{Effect of substrate concentration on enzymatic activities in the SPIPLC fraction}

The hydrolysis effect of $p N P P$ and PPi by PIPLCreleased alkaline phosphatase was studied using AMPOL ( $100 \mathrm{mM}, \mathrm{pH}=10.5$, containing $2 \mathrm{mM} \mathrm{MgCl}$ ) and TRIS.HCl ( $100 \mathrm{mM}, \mathrm{pH}=8$ ) buffers, respectively, and by varying the concentrations of $p N P P(0.01$ to $20 \mathrm{mM})$ and PPi (0.001 to $2 \mathrm{mM})$.

\subsection{Action of compounds on enzymatic activities in the SPIPLC fraction}

The study of the effect of different compounds (Levamisole, Theophylline, Zinc, Phosphate, and EDTA) on the $p$ NPPase and PPase activities of the alkaline phosphatase was performed using concentrations ranging from $100 \mu \mathrm{M}$ to $100 \mathrm{mM}$, depending on the compound.

\subsection{Protein dosage}

Protein concentration $(\mathrm{mg} / \mathrm{mL})$ was determined by the method proposed by Bradford (1976) using a commercial Bio-Rad ${ }^{\circledR}$ kit following manufacturer's specifications using bovine serum albumin (BSA) as a protein standard.

Since the compounds were evaluated in punctual concentrations, they were compared in percentage of activity with controls.

\subsection{Analysis of results}

Statistical analyzes were performed using Assistat software version 7.7 beta (Silva and Azevedo, 2016). All results were subjected to analysis of variance. Error normality was evaluated (Kolmogorov-Smirnov) to ensure the assumption of the analysis. Given the significant interaction between the factors, the development was performed. Observing a significant difference between the variables analyzed, the averages of the splits were compared using the Tukey test at a 5\% probability. GraphPad Prism (version 5.01) was used to estimate the values of $\mathrm{V}_{\max }$ and $\mathrm{K}_{\mathrm{m}}$ and Hill coefficient.

\section{Results}

Table 1 shows protein concentration $(\mathrm{mg} / \mathrm{mL})$, recovery factor (RF), and enzymatic activities (ATV) in all fractions during protein purification.
The results show that alkaline phosphatase was purified, since there was a decrease in the protein concentration of the sample and an increase in the recovery factor (RF) at each step, as well as an increase in enzymatic activity in the fraction of interest (SPIPLC) (see Table 1).

The present work also aimed to study the kinetic activities of alkaline phosphatase, so after protein purification, the SPIPLC fraction of each sample was used to continue the studies. Thus, because it was not possible to dose the proteins nor to detect the activities of alkaline phosphatase in the SPIPLC fraction of the frog diaphysis (see Table 1), only the other three samples were used in the post protein purification assays.

The analysis of variance shows an association between enzyme activity and bone regions (see Table 2), with rising activities in the following order: Tadpole Epiphysis (680.77 nmol/min/mg), Tadpole Diaphysis (1,330.51 nmol/min/mg) and Frog Epiphysis $(1,853.31 \mathrm{nmol} / \mathrm{min} / \mathrm{mg})$. The results show statistical differences between enzyme activities considering the bone regions of tadpole and frog (see Table 3), indicating that the bone region with significantly higher values for both enzymes is in the frog epiphysis, followed by tadpole diaphysis, and the lowest values were observed in the tadpole epiphysis. In this sense, according to the statistical analysis, shown in Table 3, both pNPPase and PPase activities differed when all bone regions are compared.

The study of the $\mathrm{pH}$ effect on the $p$ NPPase and PPase activities of the PIPLC-released alkaline phosphatase present in the SPIPLC fraction (see Figures 1 and 2) revealed that the apparent optimum $\mathrm{pH}$ of $\mathrm{pNPP}$ and PPi hydrolysis were, respectively, 10.5 and 8.0 , both in the epiphysis and diaphysis of tadpoles and in the frogs epiphysis.

The study of the effect of different compounds on the activities of alkaline phosphatase released by PIPLC in the SPIPLC fraction (see Table 4) showed a similar behavior when independently comparing the residual activity of pNPPase and PPase in different bone regions.

The study of the effect of the concentration of $p$ NPP and PPi substrates on the activity of alkaline phosphatase released by PIPLC was carried out in the SPIPLC fraction of tadpoles' epiphysis and diaphysis and frogs' epiphysis (see Table 5). $\mathrm{V}_{\max }$ values (see Table 5) for pNPPase and PPase differed, but followed the same pattern when comparing the different bone regions, being higher in frog epiphyses, followed by tadpole diaphysis and being lower in tadpole epiphysis.

\section{Discussion}

The activities of alkaline, acid and acid tartrate-resistant phosphatases were studied in the different anatomical regions of the femur, diaphysis and epiphysis, and in the different life stages of the animal, larval and adult (see Table 1), to follow and understand the ossification processes from the beginning of formation to the growth in thickness and length of the bones of members of the Lithobates catesbeianus species.

The $p$ NPPase and PPase activities of alkaline phosphatase in all protein purification fractions present numerically 
Table 1. Protein concentration, enzymatic activities $\left(\mathrm{U}_{\mathrm{mg}}{ }^{-1}\right)$ and recovery factors in protein purification fractions, in the epiphysis and diaphysis of tadpoles and frogs of Lithobates catesbeianus.

\begin{tabular}{|c|c|c|c|c|c|c|c|c|c|}
\hline \multirow{2}{*}{$\begin{array}{l}\text { Regions/ } \\
\text { Fractions }\end{array}$} & \multirow{2}{*}{$\begin{array}{l}\text { Protein } \\
(\mathrm{mg} / \mathrm{mL})\end{array}$} & \multicolumn{2}{|c|}{ pNPPase } & \multicolumn{2}{|l|}{ PPase } & \multicolumn{2}{|l|}{ Ac.P. } & \multicolumn{2}{|c|}{ T.R.Ac.P. } \\
\hline & & ATV & $\mathbf{R F}$ & ATV & $\mathbf{R F}$ & ATV & RF & ATV & $\mathbf{R F}$ \\
\hline \multicolumn{10}{|c|}{ Tadpole Epiphysis } \\
\hline CES & $4.13 \pm 0.13$ & $94.42 \pm 3.97$ & 1.00 & $47.00 \pm 1.36$ & 1.00 & $45.65 \pm 1.35$ & 1.00 & $22.90 \pm 0.94$ & 1.00 \\
\hline S1 & $3.84 \pm 0.01$ & $42.31 \pm 0.25$ & 0.45 & $20.64 \pm 0.68$ & 0.44 & $19.91 \pm 0.45$ & 0.44 & $7.15 \pm 0.18$ & 0.31 \\
\hline P1 & $0.35 \pm 0.02$ & $622.01 \pm 24.07$ & 6.59 & $408.29 \pm 13.18$ & 8.69 & $305.28 \pm 11.26$ & 6.69 & $190.78 \pm 3.53$ & 8.33 \\
\hline SPIPLC & $0.06 \pm 0.00$ & $675.98 \pm 19.44$ & 7.16 & $685.56 \pm 15.03$ & 14.59 & $32.77 \pm 0.48$ & 0.72 & ND & ND \\
\hline PPIPLC & $0.25 \pm 0.00$ & $794.23 \pm 11.83$ & 8.41 & $428.30 \pm 33.54$ & 9.11 & $348.06 \pm 7.76$ & 7.63 & $213.68 \pm 4.69$ & 9.33 \\
\hline \multicolumn{10}{|c|}{ Tadpole Diaphysis } \\
\hline CES & $3.40 \pm 0.26$ & $124.90 \pm 2.20$ & 1.00 & $77.68 \pm 2.69$ & 1.00 & $35.85 \pm 1.48$ & 1.00 & $16.57 \pm 0.52$ & 1.00 \\
\hline S1 & $3.14 \pm 0.12$ & $52.98 \pm 1.74$ & 0.42 & $39.04 \pm 1.78$ & 0.50 & $20.78 \pm 1.30$ & 0.58 & $6.62 \pm 0.38$ & 0.40 \\
\hline P1 & $0.15 \pm 0.01$ & $1,249.12 \pm 19.42$ & 10.00 & $736.45 \pm 27.17$ & 9.48 & $248.92 \pm 14.15$ & 6.94 & $115.99 \pm 9.51$ & 7.00 \\
\hline SPIPLC & $0.03 \pm 0.00$ & $1,028.08 \pm 15.43$ & 8.23 & $1,632.94 \pm 23.53$ & 21.02 & $29.59 \pm 0.84$ & 0.83 & $21.59 \pm 1.83$ & 1.30 \\
\hline PPIPLC & $0.07 \pm 0.00$ & $1,911.16 \pm 11.19$ & 15.30 & $1,532.56 \pm 20.13$ & 19.73 & $222.83 \pm 5.56$ & 6.22 & $116.56 \pm 14.02$ & 7.03 \\
\hline \multicolumn{10}{|c|}{ Frog Epiphysis } \\
\hline CES & $0.68 \pm 0.03$ & $221.45 \pm 7.29$ & 1.00 & $219.14 \pm 0.77$ & 1.00 & $38.25 \pm 1.42$ & 1.00 & $20.03 \pm 1.33$ & 1.00 \\
\hline S1 & $0.58 \pm 0.01$ & $80.34 \pm 2.48$ & 0.36 & $68.62 \pm 0.83$ & 0.31 & $23.99 \pm 0.67$ & 0.63 & $15.63 \pm 0.58$ & 0.78 \\
\hline P1 & $0.05 \pm 0.00$ & $2,174.30 \pm 57.59$ & 9.82 & $1,327.37 \pm 6.15$ & 6.06 & $113.86 \pm 4.54$ & 2.98 & $37.42 \pm 12.43$ & 1.87 \\
\hline SPIPLC & $0.03 \pm 0.00$ & $1,723.65 \pm 30.31$ & 7.78 & $1,982.97 \pm 83.96$ & 9.05 & $13.27 \pm 0.88$ & 0.35 & ND & ND \\
\hline PPIPLC & $0.04 \pm 0.00$ & $2,742.73 \pm 19.23$ & 12.39 & $1,072.35 \pm 14.07$ & 4.89 & $109.94 \pm 4.81$ & 2.87 & $32.87 \pm 8.01$ & 1.64 \\
\hline \multicolumn{10}{|c|}{ Frog Diaphysis } \\
\hline CES & $0.17 \pm 0.03$ & $0.819 \pm 0.10$ & 1.00 & ND & ND & $3.644 \pm 0.06$ & 1.00 & $1.146 \pm 0.09$ & 1.00 \\
\hline S1 & $0.15 \pm 0.01$ & $0.470 \pm 0.03$ & 0.57 & ND & ND & $3.423 \pm 0.09$ & 0.94 & $1.058 \pm 0.05$ & 0.92 \\
\hline P1 & ND & ND & ND & ND & ND & ND & ND & ND & ND \\
\hline SPIPLC & ND & ND & ND & ND & ND & ND & ND & ND & ND \\
\hline PPIPLC & ND & ND & ND & ND & ND & ND & ND & ND & ND \\
\hline
\end{tabular}

pNPPase = PIPLC-released alkaline phosphatase $p$-nitrophenylphosphatase activity; Ppase = alkaline phosphatase pyrophosphatase activity; Ac.P. $=$ acid phosphatase; T.R.Ac.P. = Tartrate Resistant Acid Phosphatase; ATV = Enzyme Activity; RF = Recovery Factor; ND = Not Detected.

higher values than the activities of acid and acid tartrate-resistant phosphatases in both the epiphysis and diaphysis of tadpoles (see Table 1). Alkaline phosphatase is a biochemical marker of osteoblasts, whereas tartrateresistant acid phosphatase is considered a biochemical marker of osteoclasts (Gijsbers et al., 2001; Johnson et al., 2000; Pizauro Junior et al., 2017). It can be said that, at this stage, there is greater bone growth than resorption, both in thickness and length, since the limbs of the animal are at the beginning of its development (Felisbino and Carvalho, 1999, 2001; Junqueira and Carneiro, 2013).

Alkaline phosphatase activity is higher in the diaphysis than in the tadpole epiphysis, while acid phosphatases activity is higher in the epiphysis than in the diaphysis (as shown in Table 1), indicating that bones begin to form at the center, following towards the ends (Çiçek et al., 2011; Felisbino and Carvalho, 1999, 2001; Florencio-Silva et al., 2015; Fröbisch, 2008; Gómez et al., 2017; Junqueira and Carneiro, 2013; Long and Ornitz, 2013; Pizauro Junior et al., 2002, 2017; Song et al., 2010; Wu et al., 2016), enabling formation, and growth in thickness and length by the two types of ossification necessary for the animal's transition from the aquatic to the terrestrial environment (Bo et al., 2018; Gao et al., 2018; Nakajima and Yaoita, 2003).

In the case of frogs (see Table 1), we can see that, in the epiphysis, enzyme activities follow the same pattern found in tadpoles, with alkaline phosphatase activity being higher than those of acid phosphatases. In the diaphysis, the values of acid phosphatases activity and the $p$ NPPase activity of alkaline phosphatase are low in fractions CES and S1, and were not detected in fractions P1, SPIPLC, and PPIPLC. In the case of PPase, no activity was detected in any of the fractions (as shown in Table 1).

The profile of the enzymatic activities in the two frog bone regions (see Table 1 ) shows that, by adulthood, the trabecular bones are already formed and are rigid enough to allow the animal to move through jumps in the terrestrial environment (Bo et al., 2018; Fabrezi et al., 2017; Gao et al., 2018; Pough el al., 2008). Therefore, the longitudinal growth of the long bones still needs to occur, 
in addition to the maintenance of its diameter, allowing the growth of the animal, as well as the increase of its body mass (Felisbino and Carvalho, 1999, 2001; Junqueira and Carneiro, 2013). In this sense, studies have shown that in already mineralized regions the alkaline phosphatase activities tend to decrease (McWhinnie et al., 1971), which can also be observed in the present work.

The study of the effect of pH on $p$ NPPase activity of alkaline phosphatase present in the SPIPLC fraction (see Figure 1) revealed similar results to those observed for alkaline phosphatase from other sources (McComb et al., 1979), as in Rana pipiens bones, with a $\mathrm{pH}=10.4$ (McWhinnie et al., 1971 ), in rat bones with a $\mathrm{pH}=9.4$ (Pizauro Junior et al., 1995), in artificial EMVs with a $\mathrm{pH}=10.0$ (Simão et al., 2010), and in tadpoles tails of Lithobates catesbeianus, with a $\mathrm{pH}=10.5$ (Gonçalves et al., 2015).

The study of the effect of $\mathrm{pH}$ on the enzymatic PPase activity of alkaline phosphatase present in the SPIPLC fraction (see Figure 2 ) revealed results similar to those obtained in research using the same substrate, as in studies with rat bones, showing an apparent optimal $\mathrm{pH}$ of 8.0 (Pizauro Junior et al., 1995; Rezende et al., 1998)

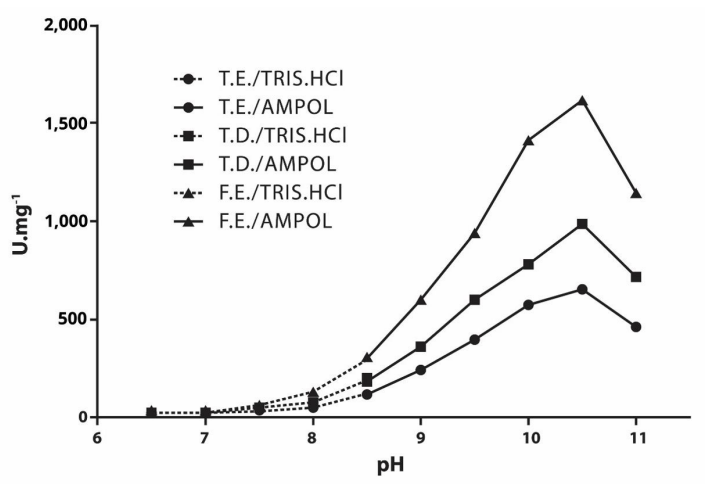

Figure 1. Effect of $\mathrm{pH}$ on $p$ NPPase activity of alkaline phosphatase released by PIPLC present in the SPIPLC fraction of tadpole epiphysis and diaphysis and frog epiphysis. T.E. = Tadpole Epiphysis; T.D. $=$ Tadpole Diaphysis; F.E. $=$ Frog Epiphysis .

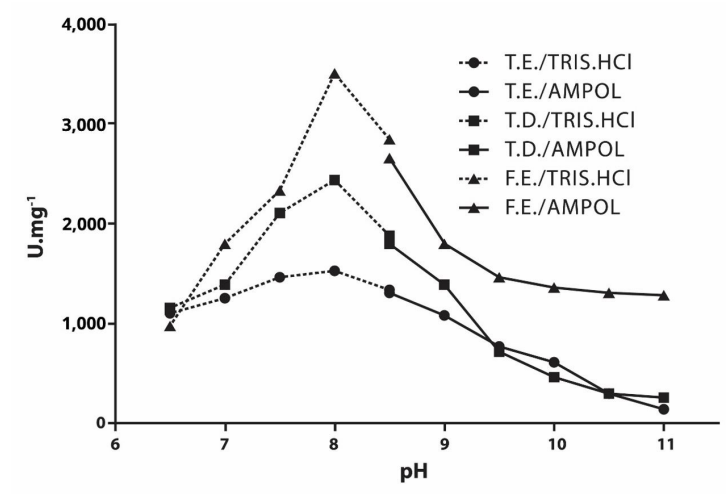

Figure 2. Effect of pH on PPase activity of alkaline phosphatase released by PIPLC present in the SPIPLC fraction of tadpole epiphysis and diaphysis and frog epiphysis. T.E. = Tadpole Epiphysis; T.D. $=$ Tadpole Diaphysis; F.E. $=$ Frog Epiphysis. and studies with artificial EMVs with a $\mathrm{pH}$ value of 9.0 (Simão et al., 2010).

The study of inhibitors makes it possible to investigate the mechanism of action and regulation of enzymatic activity, and contribute to the understanding of the role of metal ions in the maintenance, native configuration of the protein molecule, its stability, enzymatic activity and the presence of isoenzymes. In this regard, several alkaline phosphatase inhibitors are known and widely used for enzymatic characterization.

In the presence of Levamisole (100 mM) there was no inhibition (approximately 5\%) in the pNPPase activity of alkaline phosphatase of tadpole and frog bones (see Table 4), contrarily to what was shown by Simão et al. (2007) in their studies with ectopic ossification and bone marrow of rats, in which this compound was one that most inhibited this enzymatic activity. In the case of PPase activity, there was an inhibition of approximately $12 \%$, suggesting that substrate binding to the enzyme catalytic site did not lead to conformational change that exposed the inhibitor binding site (Pizauro Junior et al., 1995).

Theophylline is a structural amino acid analogue and may occupy a binding site that can be exposed when the enzyme reacts with the substrate (Farley et al., 1980). In the presence of this compound ( $1 \mathrm{mM})$, inhibition of $p$ NPPase activity was approximately $15 \%$ (see Table 4 ), relatively low compared to the values obtained in other studies (Gonçalves, 2017; Simão et al., 2007). For PPase activity, theophylline showed an inhibition of approximately $30 \%$.

Regarding the approximate $30 \%$ inhibition by zinc $(100 \mu \mathrm{M})$ in $p$ NPPase activity (see Table 4$)$, it has been proposed that this ion acts by displacing magnesium from its catalytic site, inhibiting the alkaline phosphatase activity of bone tissue (Pizauro Junior et al., 1998). However, in the study of PPase activity, performed in the absence of magnesium, there was no inhibition, suggesting that the true substrate of the enzyme is PPi and not the PPi-Mg complex (Leone et al., 1998).

In the case of inorganic phosphate $(10 \mathrm{mM})$, there was approximately a $15 \%$ inhibition of $p$ NPPase activity (see Table 4), although its concentration plays an important role in regulating the ossification process (Millán, 2013). In this sense, it has been found that alkaline phosphatase from different sources is competitively inhibited by inorganic phosphate, one of the reaction products (Pizauro Junior et al., 1988). It was not possible to perform the experiment to analyze the inhibition of this compound on PPase activity, because the methodology used when using this substrate measures the amount of inorganic phosphate released in the reaction medium (Heinonen and Lahti, 1981).

The greatest inhibition of enzymatic activity occurred in the presence of EDTA (100 mM), being approximately $67 \%$ for $p$ NPPase activity and $77 \%$ for PPase activity (see Table 4), suggesting that alkaline phosphatase from tadpoles and frogs bones of Lithobates catesbeianus is a metalloenzyme (Sharma et al., 2014), as proposed by Pizauro Junior et al. (1998) in their studies with rat bone plate, or that the compound causes conformational changes through interactions with the molecule (Curti et al., 1987). 
Table 2. ANOVA and results of the comparison of averages of specific activity of $p$ NFFase and PPase of alkaline phosphatase (nmol $/ \mathrm{min} / \mathrm{mg}$ ), in the SPIPLC fraction of protein purification, of the tadpole bone regions (epiphysis and diaphysis) and frog (epiphysis).

\begin{tabular}{ccc}
\hline & Factors & Specific activity (nmol/min/mg) \\
\hline Enzymatic activities & Bone regions & \\
\hline$p$ NPPase & & $1,142.57$ \\
PPase & Tadpole Epiphysis & $1,433.82$ \\
& Tadpole Diaphysis & 680.77 \\
& Frog Epiphysis & $1,330.51$ \\
& Analysis of variance: $p$ values & $1,853.31$ \\
\hline Enzymes & $<0.001^{* *}$ & \\
Bone regions & & $<0.001^{* *}$ \\
Enzymes X Bone regions & $<0.001^{* *}$ & \\
VC\% & $3.07 \%$ & \\
\hline
\end{tabular}

${ }^{* *}$ significant at the $1 \%$ probability level; VC\% = variation coefficient.

Table 3. Developments of enzyme activities and bone regions. Averages of $p$ NPPase and PPase specific activity of alkaline phosphatase $(\mathrm{nmol} / \mathrm{min} / \mathrm{mg})$ in protein purification of the SPIPLC fraction of tadpole and frog bone tissue regions.

\begin{tabular}{cccc}
\hline \multirow{2}{*}{ Enzymatic activities } & \multicolumn{3}{c}{ Bone regions } \\
\cline { 2 - 4 } & Tadpole Epiphysis & Tadpole Diaphysis & Frog Epiphysis \\
\hline pNPPase & $675.98 \pm 19.44^{\mathrm{C}}$ & $1,028.08 \pm 15.43^{\mathrm{bB}}$ & $1,723.65 \pm 30.31^{\mathrm{bA}}$ \\
PPase & $685.56 \pm 15.03^{\mathrm{C}}$ & $1,632.94 \pm 23.53^{\mathrm{aB}}$ & $1,982.97 \pm 83.96^{\mathrm{aA}}$ \\
\hline
\end{tabular}

Averages followed by equal letters, uppercase letters in the row and lowercase letters in the column, do not differ statistically by Tukey's test ( $\mathrm{p}>0.05$ ).

Table 4. Study of the effect of different compounds on the $p$ NPPase and PPase activities of PIPLC-released alkaline phosphatase in the SPIPLC fraction.

\begin{tabular}{|c|c|c|c|c|c|c|}
\hline \multirow{2}{*}{$\begin{array}{c}\text { Residual } \\
\text { Activity } \\
(\%)\end{array}$} & \multicolumn{6}{|c|}{ Inhibitors } \\
\hline & Control & $\begin{array}{c}\text { Levamisole } \\
(100 \mathrm{mM})\end{array}$ & $\begin{array}{c}\text { Theophylline } \\
\text { (1 mM) }\end{array}$ & $\begin{array}{c}\text { Zinc } \\
(100 \mu M)\end{array}$ & $\begin{array}{l}\text { Phosphate } \\
(10 \mathrm{mM})\end{array}$ & $\begin{array}{c}\text { EDTA } \\
(100 \mathrm{mM})\end{array}$ \\
\hline \multicolumn{7}{|c|}{ Tadpole Epiphysis } \\
\hline pNPPase & 100 & $94.20^{1}$ & 84.38 & 70.46 & 83.60 & 32.33 \\
\hline PPase & 100 & 89.80 & 69.80 & $104.08^{2}$ & $---^{3}$ & 23.67 \\
\hline \multicolumn{7}{|c|}{ Tadpole Diaphysis } \\
\hline pNPPase & 100 & $94.27^{1}$ & 83.61 & 69.54 & 83.37 & 34.41 \\
\hline PPase & 100 & 87.50 & 71.47 & $109.29^{2}$ & $---^{3}$ & 21.47 \\
\hline \multicolumn{7}{|c|}{ Frog Epiphysis } \\
\hline pNPPase & 100 & $97.48^{1}$ & 87.30 & 72.88 & 88.04 & 33.68 \\
\hline PPase & 100 & 85.63 & 70.99 & $100.28^{2}$ & $--^{3}$ & 25.35 \\
\hline
\end{tabular}

${ }^{1}$ In the case of Levamisole $(100 \mathrm{mM})$, there was no inhibition of the $p$ NPPase activity of PIPLC-released alkaline phosphatase, since only values above $5 \%$ were considered inhibitory; ${ }^{2}$ In the case of Zinc $(100 \mu \mathrm{M})$, the value higher than the Control value presented by PPase activity is not considered an activity induction because it is a subtle increase; ${ }^{3}$ The activity of PPase could not be measured in the presence of Phosphate $(10 \mathrm{mM})$ since the methodology of determination of this enzymatic activity is performed by the Phosphate Measuring released in solution after the enzyme activity.

The $\mathrm{V}_{\max }$ value in the SPIPLC fraction was 800.20, 1,157.00, and 1,885.00 U.mg-1 in the tadpole epiphysis, the tadpole diaphysis, and the frog epiphysis, respectively (see Table 5), while the $\mathrm{V}_{\max }$ values of PPase activity were 704.60, 2,093.00, and 2,248.00 $\mathrm{U.mg}^{-1}$ in the tadpole epiphysis, the tadpole diaphysis, and the frog epiphysis, respectively (see Table 5). These results demonstrate that, weather the alkaline phosphatase released by PIPLC use the chromogenic ( $p N P P$ ) or physiological (PPi) substrate, the higher activity is due to the greater formation of bone 
Table 5. Kinetic parameters for the activities (U.mg-1 \pm standard error of average) of $p$ NPPase and PPase of alkaline phosphatase present in the SPIPLC fraction.

\begin{tabular}{|c|c|c|c|c|}
\hline & \multicolumn{4}{|c|}{ Kinetic parameters } \\
\hline & $\mathbf{V}_{\text {max }}$ & $K_{m}$ & $\mathbf{n}_{\mathrm{H}}$ & $\mathbf{V}_{\max } / \mathbf{K}_{\mathrm{m}}$ \\
\hline \multicolumn{5}{|l|}{ Tadpole Epiphysis } \\
\hline pNPPase & $800.20 \pm 2.82$ & $0.63 \pm 0.009$ & $1.04 \pm 0.012$ & $1,269.76$ \\
\hline PPase & $704.60 \pm 14.77$ & $0.01 \pm 0.001$ & $1.45 \pm 0.15$ & $73,480.03$ \\
\hline \multicolumn{5}{|l|}{ Tadpole Diaphysis } \\
\hline pNPPase & $1,157.00 \pm 8.40$ & $0.59 \pm 0.017$ & $1.04 \pm 0.027$ & $1,960.68$ \\
\hline PPase & $2,093.00 \pm 57.47$ & $0.07 \pm 0.008$ & $1.10 \pm 0.12$ & $28,916.83$ \\
\hline \multicolumn{5}{|l|}{ Frog Epiphysis } \\
\hline pNPPase & $1,885.00 \pm 9.54$ & $0.60 \pm 0.012$ & $1.01 \pm 0.019$ & $3,160.63$ \\
\hline PPase & $2,248.00 \pm 96.32$ & $0.11 \pm 0.017$ & $1.00 \pm 0.16$ & $20,911.63$ \\
\hline
\end{tabular}

$\mathrm{V}_{\max }=$ maximum speed; $\mathrm{K}_{\mathrm{m}}=$ Michaelis-Menten constant; $\mathrm{n}_{\mathrm{H}}=$ Hill coefficient. The analyses were performed in GraphPad Prism version 5.01, to estimate the values of $\mathrm{V}_{\max }$ and $\mathrm{K}_{\mathrm{m}}$ the mathematical model $\mathrm{Y}=\mathrm{V}_{\max }{ }^{*} \mathrm{X} /\left(\mathrm{K}_{\mathrm{m}}+\mathrm{X}\right)$ was used. To calculate the Hill coefficient we used the model $\mathrm{Y}=\mathrm{V}_{\max }{ }^{*} \mathrm{X}^{\wedge} \mathrm{h} /\left(\mathrm{K}_{\text {prime }}+\mathrm{X}^{\wedge} \mathrm{h}\right)$.

tissue in the frog epiphysis, probably due to the size of the animal. Regarding the tadpole, the largest formation of bone tissue occurs in the diaphysis in relation to the epiphysis. In their studies with Rana catesbeiana (Lithobates catesbeianus), Felisbino and Carvalho (1999, 2001), propose that, in the larval phase, periosteal ossification is mainly responsible for growth in both diameter and length, and that in adulthood, periosteal ossification also remains primarily responsible for the growth and formation of frog limb bones, with only a small amount formed by endochondral ossification, partly responsible for the longitudinal growth of the bone tissue.

Similar apparent optimal pH (see Figures 1 and 2) and $\mathrm{K}_{\mathrm{m}}$ (see Table 5 ) values for each substrate, as well as a similar behavior of residual enzymatic activity in the presence of different compounds (see Table 4), suggests that regardless of the type of ossification occurring, the same enzyme or isoenzymes act (Sharma, Pal and Prasad, 2014) during the process in both bone regions and in the different life stages of the animal.

Statistical differences (see Tables 2 and 3) and the pattern of $V_{\max }$ values (see Table 5) of pNPPase and PPase activities confirm the pattern of bone formation and growth from the center to the extremities, because where there is a higher activity of alkaline phosphatase, more ossification occurs (Çiçek et al., 2011; Felisbino and Carvalho, 1999, 2001; Fröbisch, 2008; Gómez et al., 2017; Junqueira and Carneiro, 2013; Pizauro Junior et al., 1995, 2017; Song et al., 2010).

Comparing the apparent optimal pH(see Figures 1 and 2), $\mathrm{K}_{\mathrm{m}}$ and $\mathrm{V}_{\text {max }} / \mathrm{K}_{\mathrm{m}}$ (see Table 5) values of $p$ NPPase and PPase activities, we can suggest that PPi is the physiological substrate of alkaline phosphatase (Millán, 2006; Rezende et al., 1998), because its apparent optimal pH $(\mathrm{pH}=8.0)$ is closer to the physiological one, the lower values of $\mathrm{Km}$ indicate a higher affinity of the enzyme for $\mathrm{PPi}$, and the values of $\mathrm{V}_{\max } / \mathrm{K}_{\mathrm{m}}$ indicate a greater efficiency of enzyme activity when this substrate is used.
Regarding the values of $\mathrm{n}_{\mathrm{H}}$ (Hill coefficient) (see Table 5), it is possible to state that, among the studied samples, no site-site interaction was observed, which indicates a "Michaelian" behavior of alkaline phosphatase (Pizauro Junior et al., 1995) in the presence of the two substrates used, therefore, we can use the chromogenic artificial substrate ( $p N P P$ ) in vitro to study the behavior of this enzyme, relating to the presence of its physiological substrate (PPi) in vivo.

The present study shows that alkaline phosphatase released from the membrane by the action of $B$. cereus PIPLC presents the same kinetic properties in relation to the optimum $\mathrm{pH}$ of action, affinity for substrates, and the action of compounds in different bone regions, regardless of the type of bone ossification that is occurring, and in the different phases of the animal's life, both aquatic and terrestrial.

The data show that phosphatases activities are higher in frog epiphysis, when compared to tadpole bone regions. This effect of higher activity during $\mathrm{pH}$ studies is also observed on the other experiments. Although the specific activity is higher, the kinetic parameters are the same. With $\mathrm{pH}$ analysis we can see that despite the bone region or development stage (tadpole or frog) the same apparent optimum $\mathrm{pH}$ is observed.

The results of this work are similar to those of studies with other vertebrates, which may be indicative of the conservation of the genes of the enzymes studied during the evolutionary process, demonstrating the potential of amphibians as excellent animal models for the study of the biological mineralization process. In this regard, more studies involving gene expression of bone markers and enzymatic activity with different animal models may be important to corroborate the hypothesis that amphibians may be used as a broad ossification model. 


\section{Acknowledgements}

This work was supported by grants from FAPESP, CNPq, and CAPES

\section{References}

BO, X., WU, M., XIAO, H. and WANG, H., 2018. Transcriptome analyses reveal molecular mechanisms that regulate endochondral ossification in amphibian Bufo gargarizans during metamorphosis. Biochimica et Biophysica Acta, vol. 1862, no. 12, pp. 2632-2644. http://dx.doi.org/10.1016/j.bbagen.2018.07.032. PMid:30076880.

BRADFORD, M.M., 1976. Rapid and sensitive method for the quantitation of microgram quantities of protein utilizing the principle of protein-dye binding. Analytical Biochemistry, vol. 72, no. 1-2, pp. 248-254. http://dx.doi.org/10.1016/00032697(76)90527-3. PMid:942051.

ÇIÇEK, K., KUMAŞ, M. and AYAZ, D., 2011. Differentiation of bone tissue and long bone development in the Uludağ frog, Rana macrocnemis tadpoles. Biharean Biologist, vol. 5, no. 2, pp. 123-126.

CURTI, C., PIZAURO JUNIOR, J.M., CIANCAGLINI, P. and LEONE, F.A., 1987. Kinetic characteristics of some inhibitors of matrix-induced alkaline phosphatase. Cellular and Molecular Biology, vol. 33 , no. 5, pp. 625-635. PMid:3690615.

CZESNIK, D., KUDUZ, J., SCHILD, D. and MANZINI, I., 2006. ATP activates both receptor and sustentacular supporting cells in the olfactory epithelium of Xenopus laevis tadpoles. The European Journal of Neuroscience, vol. 23, no. 1, pp. 119-128. http://dx.doi. org/10.1111/j.1460-9568.2005.04533.x. PMid:16420422.

FABREZI, M., GOLDBERG, J. and CHULIVER PEREYRA, M., 2017. Morphological variation in anuran limbs: constraints and novelties. The Journal of Experimental Zoology. Part B, vol. 328, no. 6, pp. 546-574. http://dx.doi.org/10.1002/jez.b.22753. PMid:28597591.

FARLEY, J.R., IVEY, J.L. and BAYLINK, D.J., 1980. Human skeletal alkaline phosphatase: kinetic studies including $\mathrm{pH}$ dependence and inhibition by theophylline. The Journal of Biological Chemistry, vol. 255, no. 10, pp. 4680-4686. http://dx.doi.org/10.1016/ S0021-9258(19)85548-5. PMid:7372601.

FELISBINO, S.L. and CARVALHO, H.F., 1999. The epiphyseal cartilage and growth of long bones in Rana catesbeiana. Tissue \&'Cell, vol. 31, no. 3, pp. 301-307. http://dx.doi.org/10.1054/tice.1999.0036. PMid: 10481302 .

FELISBINO, S.L. and CARVALHO, H.F., 2001. Growth cartilage calcification and formation of bone trabeculae are late and dissociated events in the endochondral ossification of Rana catesbeiana. Cell and Tissue Research, vol. 306, no. 2, pp. 319-323. http://dx.doi.org/10.1007/s004410100446. PMid:11702243.

FLORENCIO-SILVA, R., SASSO, G.R.S., SASSO-CERRI, E., SIMÕES, M.J. and CERRI, P.S., 2015. Biology of bone tissue: structure, function and factors that influence bone cells. BioMed Research International, vol. 2015, 421746. http://dx.doi. org/10.1155/2015/421746. PMid:26247020.

FRÖBISCH, N.B., 2008. Ossification patterns in the tetrapod limb: conservation and divergence from morphogenetic events. Biological Reviews of the Cambridge Philosophical Society, vol. 83, no. 4, pp. 571-600. http://dx.doi.org/10.1111/j.1469185X.2008.00055.x. PMid:18947337.

GAO, J., LI, X., ZHANG, Y. and WANG, H., 2018. Endochondral ossification in hindlimbs during Bufo gargarizans metamorphosis: a model of studying skeletal development in vertebrates.
Developmental Dynamics, vol. 247, no. 10, pp. 1121-1134. http:// dx.doi.org/10.1002/dvdy.24669. PMid:30198600.

GIJSBERS, R., CEULEMANS, H., STALMANS, W. and BOLLEN, M., 2001. Structural and catalytic similarities between nucleotide pyrophosphatases/phosphodiesterases and alkaline phosphatases. The Journal of Biological Chemistry, vol. 276, no. 2, pp. 1361-1368. http://dx.doi.org/10.1074/jbc.M007552200. PMid:11027689.

GÓMEZ, R.O., REGUEIRA, E., O'DONOHOE, M.E.A. and HERMIDA, G.N., 2017. Delayed osteogenesis and calcification in a large true toad with a comparative survey of the timing of skeletal ossification in anurans. Zoologischer Anzeiger, vol. 267, pp. 101110. http://dx.doi.org/10.1016/j.jcz.2017.03.002.

GONÇALVES, A.M., 2017. Purificação e caracterização de isoformas de fosfomonohidrolases presentes na cauda de girinos de rã-touro (Lithobates catesbeianus) durante o desenvolvimento larval. Araraquara: Instituto de Química, Universidade Estadual Paulista, 78 p. Tese de Doutorado em Biotecnologia.

GONÇALVES, A.M., SANTOS, L.F.J., SANTANA, C.C., COLOSIO, R.R. and PIZAURO JUNIOR, J.M., 2015. Activity of tail phosphatases: a study during growth and metamorphosis of Lithobates catesbeianus. Copeia, vol. 103, no. 3, pp. 634-638. http://dx.doi. org/10.1643/OT-14-131.

GOSNER, K.L., 1960. A simplified table for staging anuran embryos and larvae with notes on identification. Herpetologica, vol. 16, no. 3, pp. 183-190.

HEINONEN, J.K. and LAHTI, R.J., 1981. A new and convenient colorimetric determination of inorganic orthophosphate and its application to the assay of inorganic pyrophosphatase. Analytical Biochemistry, vol. 113, no. 2, pp. 313-317. http:// dx.doi.org/10.1016/0003-2697(81)90082-8. PMid:6116463.

JOHNSON, K.A., HESSLE, L., VAINGANKAR, S., WENNBERG, C., MAURO, S., NARISAWA, S., GODING, J.W., SANO, K., MILLÁN, J.L. and TERKELTAUB, R., 2000. Osteoblast tissue-nonspecific alkaline phosphatase antagonizes and regulates PC-1. The American Journal of Physiology, vol. 279, no. 4, pp. R1365-R1377. PMid:11004006.

JUNQUEIRA, L.C. and CARNEIRO, J., 2013. Tecido ósseo. In: L.C. JUNQUEIRA and J. CARNEIRO, eds. Histologia básica. 12. ed. Rio de Janeiro: Guanabara Koogan, cap. 8, pp. 132-148.

KROTH, A., MACKEDANZ, V., MATTÉ, C., WYSE, A.T.S., RIBEIRO, M.F.M. and PARTATA, W.A., 2018. Effect of Sciatic Nerve Transection on acetylcholinesterase activity in spinal cord and skeletal muscles of the bullfrog Lithobates catesbeianus. Brazilian Journal of Biology = Revista Brasileira de Biologia, vol. 78, no. 2, pp. 217-223. http://dx.doi.org/10.1590/1519-6984.03016. PMid:28977043.

LEONE, F.A., REZENDE, L.A., CIANCAGLINI, P. and PIZAURO JUNIOR, J.M., 1998. Allosteric modulation of pyrophosphatase activity of rat osseous plate alkaline phosphatase by magnesium ions. Biochemistry and Cell Biology, vol. 30, no. 1, pp. 89-97. http:// dx.doi.org/10.1016/S1357-2725(97)00077-0. PMid:9597756.

LONG, F. and ORNITZ, D.M., 2013. Development of the endochondral skeleton. Cold Spring Harbor Perspectives in Biology, vol. 5, no. 1, a008334. http://dx.doi.org/10.1101/cshperspect.a008334. PMid:23284041.

MCCOMB, R. B., BOWERS JUNIOR, G. N. and POSEN, S., 1979. Alkaline phosphatase. New York: Plenum Press.

MCWHINNIE, D.J., OELTGEN, R. and STILES, D., 1971. Amphibian alkaline phosphatase - I. Biochemical characterization of alkaline phosphatase in tissues of Rana pipiens. Comparative Biochemistry and Physiology, vol. 38, no. 2, pp. 247-262. 
MILLÁN, J.L., 2006. Alkaline phosphatases: structure, substrate specificity and functional relatedness to other members of a large superfamily of enzymes. Purinergic Signalling, vol. 2, no. 2, pp. 335-341. http://dx.doi.org/10.1007/s11302-005-5435-6. PMid: 18404473.

MILLÁN, J.L., 2013. The role of phosphatase in the initiation of skeletal mineralization. Calcified Tissue International, vol. 93 , no. 4, pp. 299-306. http://dx.doi.org/10.1007/s00223-0129672-8. PMid:23183786.

NAKAJIMA, K. and YAOITA, Y., 2003. Dual mechanisms governing muscle cell death in tadpole tail during amphibian metamorphosis. Developmental Dynamics, vol. 227, no. 2, pp. 246-255. http://dx.doi.org/10.1002/dvdy.10300. PMid:12761852.

PIZAURO JUNIOR, J.M., CIANCAGLINI, P. and LEONE, F.A., 1995. Characterization of the phosphatidylinositol-specific phospholipase C-released form of rat osseous plate alkaline phosphatase and its possible significance on endochondral ossification. Molecular and Cellular Biochemistry, vol. 152, no. 2, pp. 121-129. http://dx.doi.org/10.1007/BF01076074. PMid:8751158.

PIZAURO JUNIOR, J.M., CIANCAGLINI, P. and MACARI, M., 2002. Discondroplasia tibial: mecanismos de lesão e controle. Revista Brasileira de Ciência Avícola, vol. 4, no. 3, pp. 169-186. http:// dx.doi.org/10.1590/S1516-635X2002000300001.

PIZAURO JUNIOR, J.M., CURTI, C., CIANCAGLINI, P. and LEONE, F.A., 1988. Kinetic properties of triton X-100 solubilized bone matrix induced alkaline phosphatase. Cellular and Molecular Biology, vol. 34, no. 5, pp. 553-562. PMid:3233638.

PIZAURO JUNIOR, J.M., DEMENIS, M.A., CIANCAGLINI, P. and LEONE, F.A., 1998. Kinetic characterization of a membrane-specific ATPase from rat osseous plate and its possible significance on endochondral ossification. Biochimica et Biophysica Acta, vol. 1368, no. 1, pp. 108-114. http://dx.doi.org/10.1016/S00052736(97)00174-0. PMid:9459589.

PIZAURO JUNIOR, J.M., SANTOS, L.F.J. and GONÇALVES, A.M., 2017. Estrutura e função do tecido ósseo. In: M. MACARI and A. MAIORKA, eds. Fisiologia das aves comerciais. Jaboticabal: FUNEP, cap. 19, pp. 491-513.

POUGH, F.H., JANIS, C.M. and HEISER, J.B., 2008. Salamandras, anuros e cecílias. In: F. H. POUGH, C. M. JANIS and J. B. HEISER, eds. 4. ed. A vida dos vertebrados. São Paulo: Atheneu, cap. 10 , pp. 220-263.
REZENDE, L.A., CIANCAGLINI, P., PIZAURO, J.M. and LEONE, F.A., 1998. Inorganic pyrophosphate-phosphohydrolytic activity associated with rat osseous plate alkaline phosphatase. Cellular and Molecular Biology, vol. 44, no. 2, pp. 293-302. PMid:9593580.

RIGON, F., HORST, A., KUCHARSKI, L.C., SILVA, R.S.M., FACCIONIHEUSER, M.C. and PARTATA, W.A., 2014. Effects of sciatic nerve transection on glucose uptake in the presence and absence of lactate in the frog dorsal root ganglia and spinal cord. Brazilian Journal of Biology = Revista Brasileira de Biologia, vol. 74, no. 3, suppl. 1, pp. S191-S198. http://dx.doi.org/10.1590/15196984.26012. PMid:25627385.

SHARMA, U., PAL, D. and PRASAD, R., 2014. Alkaline phosphatase: an overview. Indian Journal of Clinical Biochemistry, vol. 29, no. 3, pp. 269-278. http://dx.doi.org/10.1007/s12291-013-0408-y. PMid:24966474.

SILVA, F.A.S. and AZEVEDO, C.A.V., 2016. The Assistat Software Version 7.7 and its use in the analysis of experimental data. African Journal of Agricultural Research, vol. 11, no. 39, pp. 37333740. http://dx.doi.org/10.5897/AJAR2016.11522.

SIMÃO, A.M.S., BELOTI, M.M., CEZARINO, R.M., ROSA, A.L., PIZAURO, J.M. and CIANCAGLINI, P., 2007. Membrane-bound alkaline phosphatase from ectopic mineralization and rat bone marrow cell culture. Comparative Biochemistry and Physiology, vol. 146, no. 4, pp. 679-687. http://dx.doi.org/10.1016/j.cbpa.2006.05.008. PMid:16798036.

SIMÃO, A.M.S., YADAV, M.C., NARISAWA, S., BOLEAN, M., PIZAURO, J.M., HOYLAERTS, M.F., CIANCAGLINI, P. and MILLÁN, J.L., 2010. Proteoliposomes harboring alkaline phosphatase and nucleotide pyrophosphatase as matrix vesicles' biomimetics. The Journal of Biological Chemistry, vol. 285, no. 10, pp. 7598-7609. http:// dx.doi.org/10.1074/jbc.M109.079830. PMid:20048161.

SONG, F., LI, B. and STOCUM, D.L., 2010. Amphibians as research models for regenerative medicine. Organogenesis, vol. 6, no. 3, pp. 141-150. http://dx.doi.org/10.4161/org.6.3.12039. PMid:21197215.

TRUEB, L. and HANKEN, J., 1992. Skeletal development in Xenopus laevis (Anura: pipidae).Journal of Morphology, vol. 214, no. 1, pp. 1-41. http://dx.doi.org/10.1002/jmor.1052140102. PMid:1433306.

WU, M., CHEN, G. and LI, Y., 2016. TGF-beta and BMP signaling in osteoblast, skeletal development, and bone formation, homeostasis and disease. Bone Research, vol. 4, no. 1, 16009. http://dx.doi.org/10.1038/boneres.2016.9. PMid:27563484. 


\section{Supplementary Material}

Supplementary material accompanies this paper.

Supplementary Figure 1 - Scheme of the purification of membrane-bound proteins by phosphatidylinositol anchor and the obtaining of enzymatic extracts.

This material is available as part of the online article from https://www.scielo.br/j/BJB 